\title{
VPLIV ZRNATOSTI BRUSNEGA PAPIRJA NA EMISIJO FORMALDEHIDA IZ IVERNIH PLOŠČ
}

\section{THE IMPACT OF SANDPAPER GRIT SIZE ON FORMALDEHYDE EMISSION FROM PARTICLEBOARDS}

\author{
Sergej MEDVED ${ }^{1}$, Gregor KRAJŠEK ${ }^{2}$ \\ (1) Univerza v Ljubljani, Biotehniška fakulteta, Oddelek za lesarstvo, Rožna dolina, Cesta VIII/34, SI-1000 Ljubljana, Slovenija; \\ sergej.medved@bf.uni-lj.si \\ (2) Univerza v Ljubljani, Biotehniška fakulteta, Oddelek za lesarstvo, Rožna dolina, Cesta VIII/34, SI-1000 Ljubljana, Slovenija; \\ gregor.krajsek@gmail.com
}

\section{IZVLEČEK}

Brušenje je pomembna stopnja proizvodnje različnih lesnih ploščnih kompozitov. Njegov primarni namen je doseganje želene debeline in primerne gladkosti površine. Z brušenjem oz. izbiro zrnatosti brusnega papirja pa lahko vplivamo tudi na emisijo formaldehida. Da bi ugotovili vpliv zrnatosti uporabljenega brusnega papirja na emisijo formaldehida, smo iverne plošče brusili s papirji različne zrnatosti. Uporabili smo iverno ploščo debeline $16 \mathrm{~mm}$, ki je namenjena za pohištveno rabo. Za brušenje smo uporabili brusni papir zrnatosti 40, 80 in 120. Emisijo formaldehida smo določili po plinski metodi (SIST EN 717-2). Ugotovili smo, da se emisija formaldehida zmanjšuje z večanjem finosti uporabljenega brusnega papirja.

Ključne besede: iverna plošča, emisija formaldehida, brušenje, zrnatost

\begin{abstract}
Sanding is an important stage of wood-based panel production, where the primary goal is to achieve a desired thickness as well as appropriate smoothness of the surface. With sanding, the emission of formaldehyde can be influenced especially by the selection of sanding paper grit size. The aim of this paper is to present how the grit size of selected sanding paper affects formaldehyde emission of three-layer particleboard. For this purpose we selected $16 \mathrm{~mm}$ thick particleboard for furniture use. Sanding paper with grit sizes of 40, 80 and 120 was used for particleboard sanding. Formaldehyde emission was determined by the gas analysis method (SIST EN 717-2). The findings indicate that formaldehyde emission decreases with increasing grit size of sandpaper used in the process.
\end{abstract}

Key words: particleboard, formaldehyde emission, sanding, grit size

\section{UVOD}

\section{INTRODUCTION}

Iverne plošče so lesni ploščni kompozit z zelo širokim spektrom uporabe. Največji delež ivernih plošč se uporablja za izdelavo pohištva, kjer je poleg mehanskih lastnosti in odpornosti proti vodi pomembna tudi emisija formaldehida. Zaradi uporabe plošč v bivalnih prostorih je pomembno, da je emisija formaldehida čim nižja, saj formaldehid sodi med rakotvorne substance (IARC, 2006). Emisija formaldehida iz ivernih plošč in tudi ostalih lesnih ploščnih kompozitov je posledica rabe veziv na osnovi formaldehida in razgradnje oz. degradacije hemiceluloze in lignina (Athanassiadou in Ohlmeyer, 2008, Marutzky, 1989, Weigl in sod. 2009). Emisija formaldehida je odvisna od številnih dejavnikov, kot so npr. proizvodni postopek (Marutzky in Roffael, 1977, Schäfer in Roffael, 2000), vrste in de- lež uporabljenega lepila (Graves, 1993; Dunky, 1998), vlažnost kompozita (Johnson in sod., 2011) in starost kompozita (Zinn in sod., 1990). Emisijo formaldehida lahko po mnenju Athanassiadou in Ohlmeyer (2008) zmanjšamo z uporabo veziv z manjšim deležem formaldehida (nižje molarno razmerje formaldehid:urea ali formaldehid:urea:melamin ali formaldehid:melamin), z uporabo zadrževalcev, različnih materialov za zapiranje površine in roba (npr. furnir, papir, k je impregniran z melaminsko smolo, laminat, ABS trak itd.). Emisija formaldehida se po njunem mnenju lahko zmanjša tudi z nadaljnjo obdelavo plošč.

Ena izmed možnosti nadaljnje obdelave plošč, s katero bi lahko vplivali na emisijo formaldehida, je tudi brušenje plošč. Z brušenjem dosežemo končno oz. želeno debelino plošč, hkrati pa dosežemo njihovo primerno gladkost. Brušenje je postopek obdelave 
materiala, kjer z velikim številom rezil (brusna zrnca) odstranimo površinski del materiala ter pri tem pustimo globje ali plitkejše raze. Globina raz je odvisna od finosti oz. grobosti brusnega papirja (Nemli in sod., 2005; Hiziroglu in Suzuki, 2007; Nemli in sod., 2007; Rolleri in Roffael, 2010), kar posledično vpliva na celokupno površino materiala oz. površino, skozi katero lahko formaldehid emitira v okolico. Večja globina raz in posledično večja celokupna površina je bila ugotovljena pri rabi grobih brusnih papirjev.

Namen prispevka je prikazati vpliv zrnatosti brusnega papirja na emisijo formaldehida iz trislojnih ivernih plošč.

\section{MATERIALI IN METODE}

\section{MATERIALS AND METHODS}

Za izvedbo raziskave smo uporabili komercialno dostopne trislojne iverne plošče oznake P2 (SIST EN 312). Plošče so namenjene uporabi v normalnih klimatskih pogojih. Kot vezivo je je bilo uporabljeno ureaformaldehidno lepilo. Debelina uporabljenih plošč je bila $16 \mathrm{~mm}$, gostota pa $0,650 \mathrm{~g} / \mathrm{cm}^{3}$.

Preskušance velikosti $400 \times 50 \mathrm{~mm}^{2}$ smo po sedemdnevnem klimatiziranju pri normalnih klimatskih pogojih (temperatura $20^{\circ} \mathrm{C}$ in $65 \%$ relativna zračna vlažnost) zbrusili z brusnimi papirji zrnatosti 40, 80 in 120. Izbrani brusni papirji se uporabljajo tudi pri proizvodnji, in sicer za brušenje plošč, pri čimer se brusni papirji zrnatosti 40 uporabljajo za grobo brušenje plošč, brusni papirji zrnatosti 120 pa za končno (fino) brušenje plošč. Brušenje je potekalo ročno in relativno enakomerno po obeh ploskvah z odvzemom približno
$1 \mathrm{~mm}$ (slika 1). Ena serija preskušancev je ostala nebrušena (kontrolni preskušanci).

Emisijo formaldehida smo določili po plinski metodi (SIST EN 717-2). Pred izvedbo preskusa smo robove plošč (v skladu z zahtevo standarda) zaprli z aluminijastim samolepilnim trakom. Tako pripravljen preskušanec smo nato vstavili v komoro z notranjim volumnom $4017 \mathrm{~mL}$ (slika 2). Pogoji v komori so bili naslednji:

- temperatura: $60 \pm 0,5^{\circ} \mathrm{C}$

- relativna zračna vlažnost: $2 \pm 1 \%$

- pretok zraka: $60 \pm 3 \mathrm{l} / \mathrm{h}$

Na komoro so prek elektromagnetnih ventilov povezane $4 \times 2$ izpiralne stekleničke, v katerih se nahaja od 30 do $40 \mathrm{~mL}$ destilirane vode. Zrak iz komore se za vsako uro posebej ločeno vodi prek para izpiralnih stekleničk, kjer formaldehid nato iz zraka preide v destilirano vodo.

Po preteku 4 ur smo vodno raztopino (destilirana voda in formaldehid) iz izpiralnih stekleničk ločeno za vsako uro posebej prelili v merilno bučko. Nato smo dolili destilirano vodo do oznake $250 \mathrm{~mL}$. Vse skupaj smo premešali in iz vodne raztopine odpipetirali $10 \mathrm{~mL}$ (alikvot). Alikvotu smo nato dodali $10 \mathrm{~mL}$ acetil acetona in $10 \mathrm{~mL}$ amonijevega acetata. Dodatek omenjenih reagentovo omogoči nastanek t. i. Hantzscheve reakcije (reakcija, značilna za formaldehid), pri kateri formaldehid v vodni raztopini reagira $\mathrm{z}$ amonijevimi ioni in acetil acetonom, pri čimer nastane diacetildihidrolutidin (DDL), ki ima absorpcijski maksimum pri $412 \mathrm{~nm}$. Epruveto z vodno raztopino in reagenti smo zatesnili, premešali in postavili $v$ vodno kopel s temperaturo 40

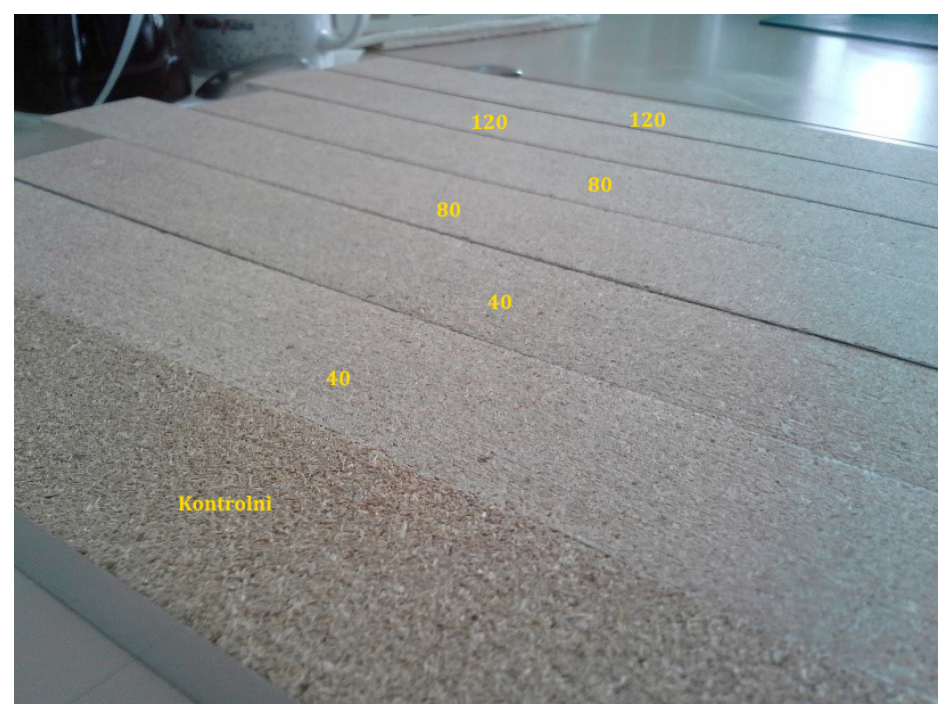

Slika 1: Videz površine preskušancev (spodaj: nebrušen kontrolni preskušanec; 40: brušen z brusnim papirjem zrnatosti 40; 80: brušen z brusnim papirjem zrnatosti 80; in 120: brušen z brusnim papirjem zrnatosti 120)
Fig. 1: Sample surface (bottom: unsanded/control; 40: sanded with grit paper mark 40; 80: sanded with grit paper mark 80; and 120: sanded with grit paper mark 120) 


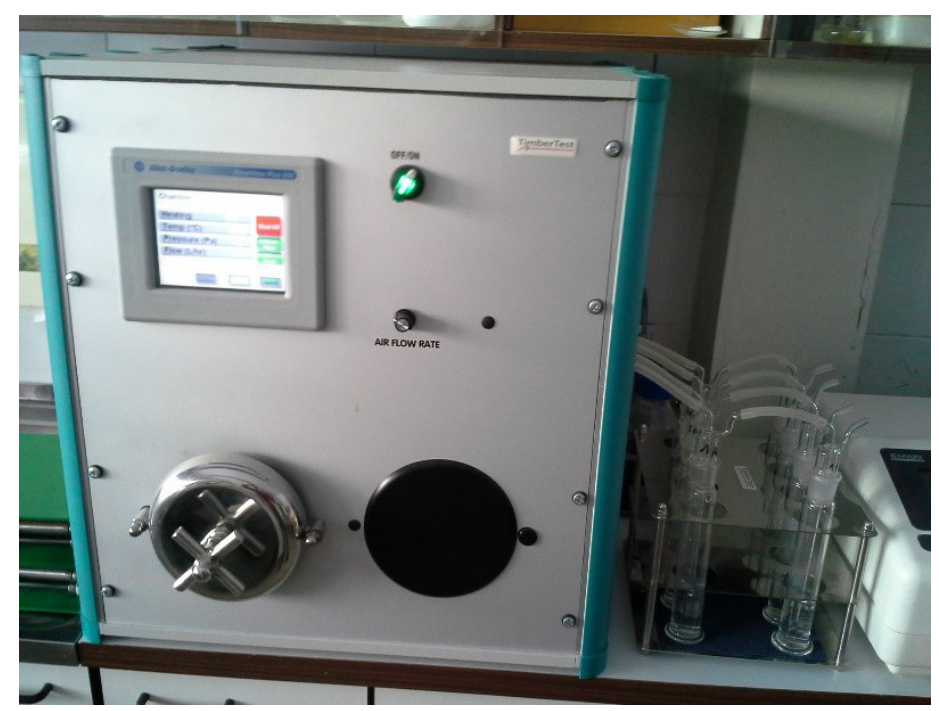

Slika 2: Komora za plinsko analizo

${ }^{\circ} \mathrm{C}$. Po 15 minutah smo epruvete za eno uro postavili $\mathrm{v}$ temen prostor, nato pa s spektrofotometrom določili absorpcijo pri $412 \mathrm{~nm}$. Emisijo formaldehida smo za vsako uro posebej izračunali po enačbi 1, povprečno emisijo pa po enačbi 2 :

$G_{i}=\frac{\left(A_{s}-A_{b}\right) \times f \times V}{F}$

kjer je:

$\mathrm{G}_{\mathrm{i}}$ emisija formaldehida za vsako uro posebej $\mathrm{v}$ $\mathrm{mg} / \mathrm{m}^{2} \mathrm{~h}$

i prva, druga, tretja in četrta ura določanja emisije

$A_{s}$ absorpcija preskušanca

$A_{b}$ absorpcija, določena pri destilirani vodi (slepa proba)

f naklon kalibracijske krivulje

$\mathrm{F}$ površina emitiranja formaldehida $\mathrm{v} \mathrm{m}^{2}$

$\mathrm{V}$ volumen merilne bučke $\mathrm{v} \mathrm{mL}(250 \mathrm{~mL})$

$G_{m}=\frac{G_{1}+G_{2}+G_{3}+G_{4}}{4}$

kjer je:

$G_{m}$ povprečna emisija formaldehida $v \mathrm{mg} / \mathrm{m}^{2} \mathrm{~h}$

Poleg emisije formaldehida smo določili tudi vsebnost vlage (SIST EN 322). Preskušance z maso najmanj 20 g smo za 16 ur postavili v sušilnik s temperaturo $103 \pm 2{ }^{\circ} \mathrm{C}$. Iz razlik v masi smo po enačbi 3 izračunali vsebnost vlage:

$$
H=\frac{\Delta m}{m_{0}}=\frac{m_{H}-m_{0}}{m_{0}}
$$

kjer je:

$\mathrm{H}$ vsebnost vlage v \%

$\mathrm{m}_{\mathrm{H}}$ masa vlažnega preskušanca $\mathrm{v} g$

$\mathrm{m}_{0}$ masa suhega preskušanca $\mathrm{v} g$
Fig. 2: Gas analysis test chamber

\section{REZULTATI IN RAZPRAVA}

3 RESULTS AND DISCUSSION

Ugotavljamo, da finost brusnega papirja vpliva tako na emisije formaldehida kot tudi na vsebnost vlage (slika 3 in slika 4).

Vidimo, da se tako emisija formaldehida kot tudi vsebnost vlage zmanjšujeta $\mathrm{z}$ večanjem finosti brusnega papirja. Grobi brusni papir (brusni papir oznake 40) ima na nosilno podlago pritrjenih sicer manj abrazivnih delcev, ki pa so znatno večji in povzročijo tudi globje raze na površini (kar vodi do večje hrapavosti (Nemli in sod., 2007, Luo in sod., 2014)). Zaradi dejansko večje celokupne površine, ki nastane z uporabo grobih brusnih papirjev, je emitiranje formaldehida iz plošče v okolico lažje, kar posledično pomeni večjo emisijo formaldehida. Pri uporabi bolj grobih brusnih papirjev večja hrapavost ni zgolj posledica uporabe večjih abrazivnih delcev, temveč prihaja tudi do iztrganja slabo spojenih iveri iz površine, medtem ko se pri uporabi finejših brusnih papirjev površina deloma tudi gladi oz. zapira (Nemli in sod., 2007, Luo in sod., 2014). Čeprav je, pri finih brusnih papirjih število abrazivnih delcev večje, kar prav tako povzroči večanje površine emitiranja, pa je pri teh papirjih globina razenja bistveno manjša. Hkrati ne smemo pozabiti oz. zanemariti učinka glajenja oz. zapiranja površine pri brušenju s finejšimi brusnimi papirji, ki pomembno vpliva na zmanjšanje emisije formaldehida.

Če primerjamo izključno rezultate emisije formaldehida in vlažnosti za brušene plošče, lahko ugotovimo, da je emisija formaldehida odvisna tudi od vlažnosti plošče (slika 5), slednja pa je odvisna tudi od hrapavosti površine.

Čeprav je ugotovljena korelacija med vlažnostjo plošč in emisijo formaldehida (Johnson in sod., 2011), 


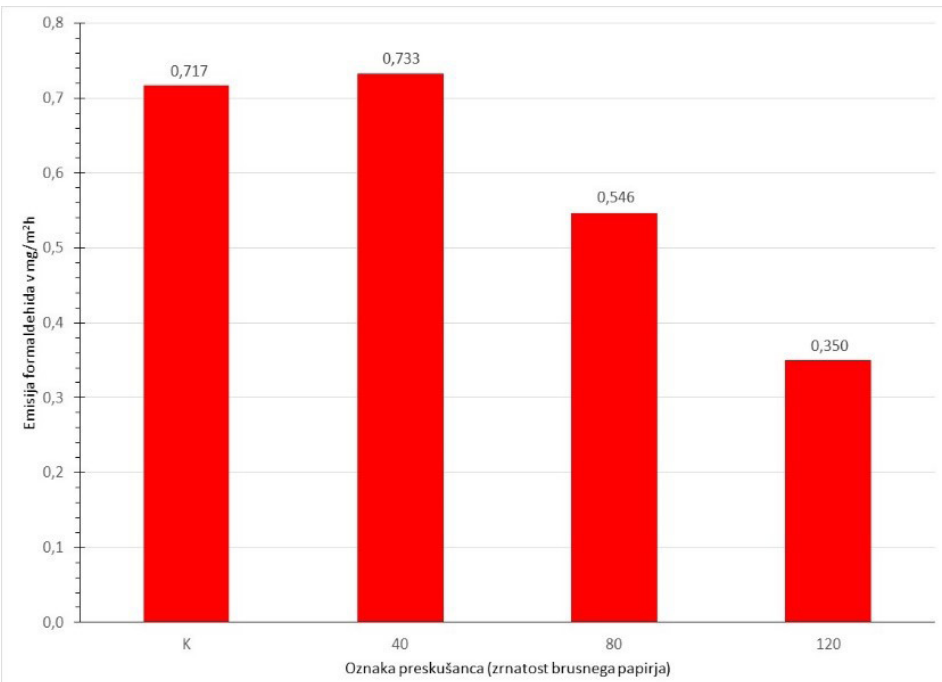

Slika 3: Emisija formaldehida v odvisnosti od zrnatosti uporabljenega brusnega papirja
Fig. 3: Formaldehyde emission relative to the grit size of the used sandpaper

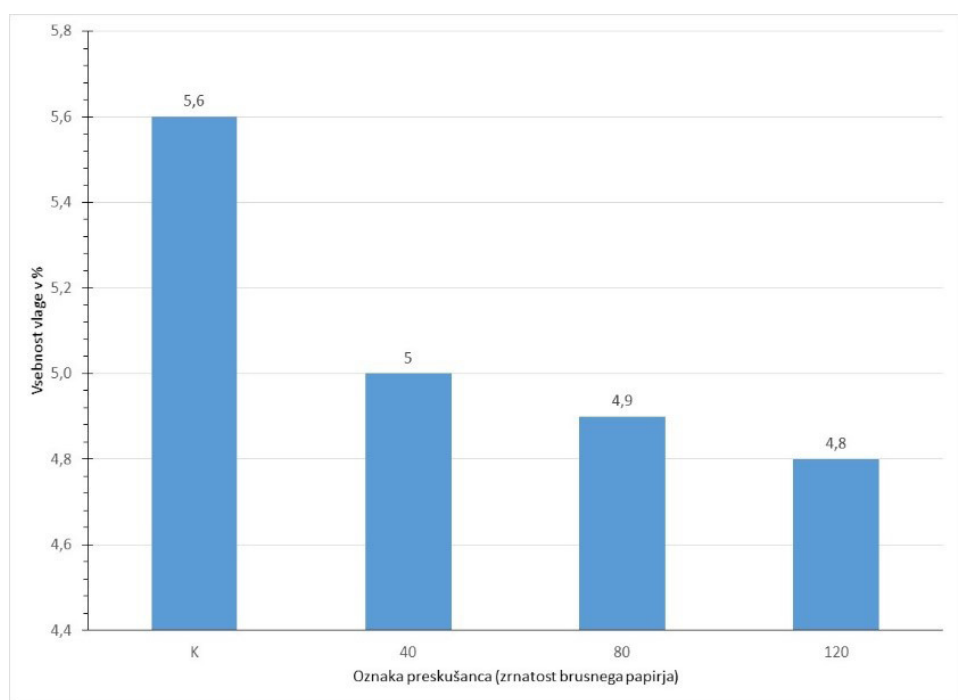

Slika 4: Vsebnost vlage preskušanca v odvisnosti od zrnatosti uporabljenega brusnega papirja
Fig. 4: Moisture content of samples relative to the grit size of the used sandpaper

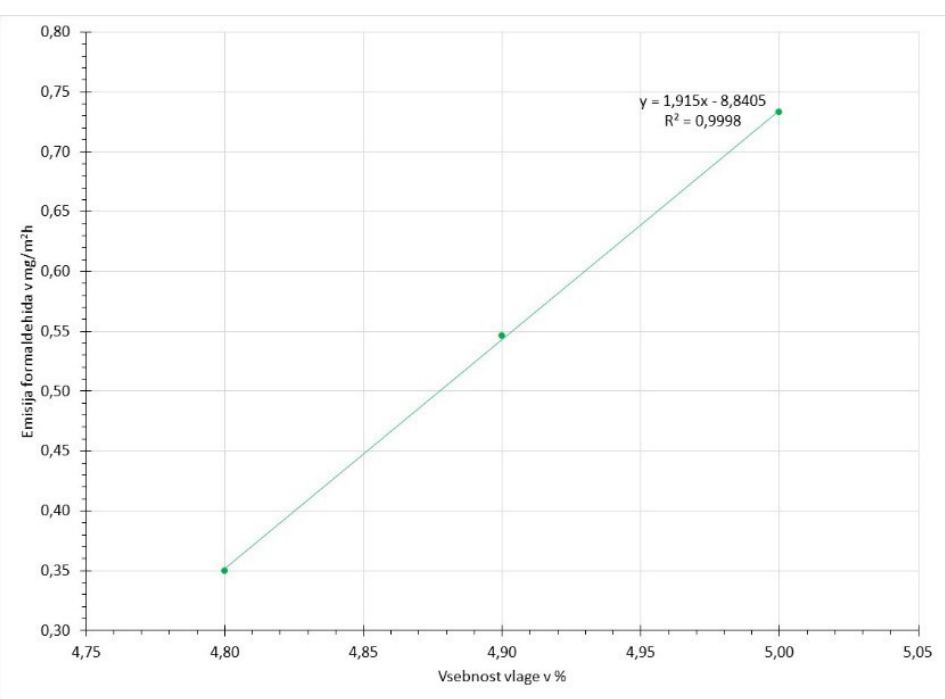

Slika 5: Emisija formaldehida v odvisnosti od vlažnosti plošče

Fig. 5: Formaldehyde emission relative to moisture content 
pa pri naši raziskavi ne moremo trditi, da je vlažnost plošč glavni razlog večje emisije formaldehida pri uporabi papirja zrnatosti 40 , saj je razlika v vlažnosti preskušancev relativno majhna $(0,2 \%)$. Kljub pomembnejši vlogi povečane emisijske površine pa vpliva vlažnosti ne smemo zanemariti.

Glede na rezultate meritev bi bilo pri proizvodnji lesnih ploščnih kompozitov iz iveri (iverne plošče) in vlaknenih plošč (HDF, MDF) smiselno brušenje v dveh korakih, pri čimer naj bi med prvim in drugim brušenjem preteklo nekaj dni. Zaradi večje emisijske površine in posledično večje ugotovljene emisije formaldehida po brušenju lahko predvidevamo, da bodo plošče, brušene $\mathrm{z}$ grobimi papirji, hitreje dosegle emisijsko ravnovesje kakor tiste, ki so bile brušene s finejšimi papirji.

\section{ZAKLJUČKI}

\section{CONCLUSIONS}

V raziskavi smo ugotavljali vpliv zrnatosti brusnega papirja na emisijo formaldehida iz trislojnih ivernih plošč. Ugotovili smo, da izbira brusnega papirja vpliva na emisijo formaldehida, saj smo največjo emisijo določili pri plošči, ki smo jo brusili s papirjem zrnatosti 40, najmanjšo pa pri uporabi papirja zrnatosti 120.

\section{SUMMARY}

\section{POVZETEK}

Particleboards are the most widely used type of wood-based panels. The majority of particleboards are used in furniture industry, where formaldehyde emission is extremely important. According to IARC (2006), formaldehyde is classified as a substance that is a human carcinogen. Formaldehyde emission form wood-based panels is are result of the use of formaldehyde-based adhesives and the degradation process of hemicellulos and lignin (Marutzky, 1989; Athanassiadou and Ohlmeyer, 2008; Weigl et al., 2009). Formaldehyde emission is affected by the production process, the type and share of adhesive, moisture content and the age of the composite (Marutzky and Roffael, 1977; Zinn et al., 1990; Graves, 1993; Dunky,

Table 1: Formaldehyde emission and moisture content relative to sandpaper grit size
1998; Schäfer and Roffael, 2000; Johnson et al., 2011). Several different options are available in order to reduce formaldehyde emission, such as lowering the formaldehyde:urea or formaldehyde:urea:melamine: formaldehyde:melamine molar ration, the use of formaldehyde scavenger, surfacing and edging material, and post-treatment of panels (Athanassiadou and Ohlmeyer, 2009). One of the options to reduce formaldehyde emission could be sanding. The aim of this paper is to demonstrate the impact of sanding on formaldehyde emission from particleboard by using sandpaper with different grit sizes.

Commercially available $16 \mathrm{~mm}$ three-layer particleboards with a density of $0.650 \mathrm{~g} / \mathrm{cm}^{3}$ were used. For the purpose of this research. The particleboards were P2 grade (SIST EN 312) intended for use in dry conditions. Formaldehyde emission was determined by gas analysis method (SIST EN 717-2). Samples measuring $400 \times 50 \mathrm{~mm}^{2}$ were sanded by hand using grit paper sizes of 40, 80 and 120 . In all the cases approximately $1 \mathrm{~mm}$ of the surface was removed with sanding, which was conducted on both sides of climatized. All the edges were closed using self-adhesive aluminium tape samples in accordance with the said standard (SIST EN 717-2). The samples were then placed in a chamber that was heated to the adequate temperature of 60 $\pm 0.5^{\circ} \mathrm{C}$. The level of humidity in the chamber was 2 $\pm 1 \%$ and the air flow into the chamber was $60 \pm 3$ $\mathrm{l} / \mathrm{h}$. Four sets of wash bottles containing from 30 to 40 $\mathrm{mL}$ of distilled water were connected to the chamber. Formaldehyde emission was measured for 4 hours at hourly intervals. After 4 hours the water solution from wash bottles was transferred into a $250 \mathrm{~mL}$ volumetric flask to which distilled water was added to the indicated mark. The water solution $(10 \mathrm{~mL})$ was transferred from the volumetric flask to another flask to which we added $10 \mathrm{~mL}$ of acetyl acetone and $10 \mathrm{~mL}$ of ammonium acetate solution. The flask was stoppered, shaken and placed in a water bath with temperature $40{ }^{\circ} \mathrm{C}$ for 15 minutes. The solution was then placed in a dark chamber for one hour. The absorption of the solution was determined using a spectrophotometer at 412

Preglednica 1: Emisija formaldehida in vsebnost vlage glede na zrnatost uporabljenega brusnega papirja

\begin{tabular}{|c|c|c|}
\hline Sandpaper grit size & $\begin{array}{c}\text { Formaldehyde emission } \\
\mathrm{mg} / \mathrm{m}^{2} \mathrm{~h}\end{array}$ & $\begin{array}{c}\text { Moisture content } \\
\%\end{array}$ \\
\hline Control & 0,717 & 5,6 \\
\hline 40 & 0,733 & 5,0 \\
\hline 80 & 0,546 & 4,9 \\
\hline 120 & 0,350 & 4,8 \\
\hline
\end{tabular}


nm. Formaldehyde emission was calculated according to equations 1 and 2. Moisture content of the samples was determined according to SIST EN 322.

We found that that formaldehyde emission and moisture content were affected by the grit size of the sandpaper used in the process (Table 1).

Sanding of particleboards with coarser sandpaper creates deeper abrasions, which provides more surface through which formaldehyde can emit from the board and into the environment, hence higher emissions were recorded. Although sandpaper with larger grit sizes causes more abrasions, such abrasions are more shallow (smoother surface), which results in lower formaldehyde emission.

\section{ZAHVALA}

\section{ACKNOWLEDGEMENT}

Avtorji se zahvaljujejo Javni agenciji za raziskovalno dejavnost Republike Slovenije za podporo pri izvedbi raziskave v okviru programa P4-0015 (Les in lignocelulozni kompoziti).

\section{VIRI}

\section{LITERATURE}

Athanassiadou E., Ohlmeyer M. 2009. Emission of Formaldehyde and VOC from Wood - based Panels V: COST action WG3 (E49) - Performance in use and new products of wood based composites. Fan M., Ohlmeyer M., Irle M., Haelvoet W., Athanassiadouand E., Rochester I. (ur.). London: Brunel University Press; 219 - 240

Dunky M. 1998. Urea-formaldehyde (UF) adhesive resins for wood. International Journal of Adhesives and Adhesion, 18: 95-107

Graves G. 1993. Formaldehyde emission control via resin technology. North American practices. Proceedings of the 27th international particleboard and composite materials symposium, Washington State University, Pullman, Washington: 221-232.

Hiziroglu S., Suzuki S. 2007. Evaluation of surface roughness of commercially manufactured particleboard and medium density fiberboard in Japan. Journal of Materials Processing Technology, 184: $436-440$
IARC 2006. Formaldehyde, 2-butoxyethanol and 1-tert-butoxypropan-2-ol. IARC Monographs on Evaluation of Carcinogenic Risks to Humans, 88: 1-478

Johnsson B., Engström B., Roffael E. 2011. Wood Science and Technology, 45: 389-398

Luo B., Li, L., Liu H., Xu M., Xing F. 2014. Analysis of Sanding Parameters, Sanding Force, Normal Force, Power Consumption, and Surface Roughness in Sanding Wood-Based Panels. BioResources, 9, 4: 7494-7503

Marutzky R. 1989. Release of Formaldehyde by Wood Products. V: Wood Adhesives - Chemistry and Technology, Volume 2. Pizzi A. (ur.) New York, Marcel Dekker, inc.: 307-374

Marutzky R., Roffael E. 1997. Über die Abspaltung von Formaldehyde bei der Termischen Behandlung von Holzspänen: Teil 1: ModellVersuche. Holzforschung, 31: 8-12

Nemli G., Ozturk I., Aydin I. 2005. Some of the parameters influencing surface roughness of particleboard. Building and Environment, 40: 1337-1340

Nemli G., Akbulut T., Zekoviç E. 2007. Effect of Some Sanding Factors on the Surface Roughness of Particleboard. Silva Fennica, 41, 2: 373-378

Rolleri R., Roffael E. 2010. Surface roughness of uncoated particleboards and its relation with the raw material, adhesive and climate conditions. European Journa of Wood Products, 68: 369-372

Schäfer M., Roffael E. 2000. On the formaldehyde release of wood. Holz als Roh- und Werkstoff, 58: 259-264

Zinn T.W., Cline D., Lehmann, W.F. 1990. Long-term study of formaldehyde emission decay from particleboard. Forest Products Journal, 40, 6: 15-18

Weigl M., Wimmer R., Sykacek E., Steinwender M. 2009. Wood-borne formaldehyde varying with species, wood grade, and cambial age. Forest Products Journa, 59: 88-92

SIST EN 312. Particleboards - Specifications. 2011: p. 18

SIST EN 322: Wood-based panels - Determination of moisture content. 1996: p. 7

SIST EN 717-2: Wood-based panels - Determination of formaldehyde release - Part 2: Formaldehyde release by the gas analysis method. 1996: p. 16 